\title{
Graziani's analysis of the circuit: does it extend to the era of financialisation?
}

\author{
Malcolm Sawyer* \\ University of Leeds, UK
}

This paper outlines some key features of the circuitist analysis provided by Augusto Graziani, and some key features of the processes of financialisation. It argues that the key features of the monetary circuit analysis remain relevant and indeed central to a monetary analysis. It presents a development of a circuit analysis in which some features of financialisation are incorporated. It argues that the circuitist approach provides a framework within which the detailed analysis of a specific monetary economy can be located.

Keywords: circuitist analysis, financialisation, Augusto Graziani

JEL codes: $E 1, E 50, E 44$

\section{INTRODUCTION}

The circuitist analysis as presented in Graziani (2003) provides a deep analysis of the nature and role of money, and presents a rather skeletal representation of a monetary production economy. The central issue of this paper is to ask how that skeletal representation could be developed to reflect developments in the financial system, particularly those which have been investigated under the term 'financialisation', and how that representation can be used as a framework in which empirical and theoretical analysis of a specific actual economy can be conducted.

There have been many changes over the years to the ways in which the financial sector operates, and to the relationships between households, firms, banks and financial institutions (including stock and other financial markets), and many differences between countries. The period since circa 1980 has been described by many as one of financialisation, though the term 'financialisation' has been given several meanings and interpretations. ${ }^{1}$ A widely quoted definition of financialisation is that given by Epstein (2005, p. 3): 'financialization means the increasing role of financial motives,

* Email: m.c.sawyer@lubs.leeds.ac.uk. Acknowledgements: The contents of this paper have been much influenced by conversations and discussions with Giuseppe Fontana and Macro Veronese Passarella. Discussions at the INET YSI workshop in New York on 24/26 February 2015 triggered some of the formulations used in this paper. The contents of the paper have been strongly influenced by my involvement as principal investigator in project Financialisation, Economy, Society and Sustainable Development (FESSUD), which received funding from the European Union Seventh Framework Programme (FP7/2007-2013) under grant agreement no 266800. I am grateful to two anonymous referees for comments on an initial draft. The participants in discussions and the referees are, of course, not responsible for the use which I make of those conversations and comments.

1. For some discussion on this, see Sawyer (2013). 
financial markets, financial actors and financial institutions in the operation of the domestic and international economies'. Within that broad definition given by Epstein, the recent period is often viewed in terms of expansion of the banking sector and of equity markets and the growth of what is now often termed 'shadow banking', growth of a range of financial instruments with securitisation and derivatives, the engagement of non-financial corporations in financial dealings, and the growth of consumer borrowing and household debts. ${ }^{2}$

The two central questions which this paper seeks to address are: (i) are these developments compatible with the circuitist analysis? And (ii) what amendments to the circuitist framework should be made to accommodate these developments? The broad answers which I give are that the central feature of the circuitist analysis based on the distinction between initial finance and final finance remains in place, and that two sets of amendments to the circuitist analysis are required which relate to the direction of flow of funds between the three sectors (banks, firms and households), and that the financial sector needs to be developed through recognition between clearing banks, investment banks, savings banks and non-bank financial institutions (NBFIs, now often put under the label of 'shadow banks').

\section{THE CIRCUITIST ANALYSIS OF GRAZIANI}

The circuitist analysis can be viewed as a logical exercise which starts with the loan process by a bank extended to firms to enable production to be undertaken, through the credit money (bank deposit) creation, the use and then circulation of the created bank deposit as money, and eventually repayment of the loan whereupon money is extinguished. The initial part of that process is a loan taken out by a firm in order to finance production (hence a Monetary Theory of Production). An important, and in many respects the crucial, feature of the circuitist approach is the distinction between initial finance and final finance. 'Firms need finance in order to set up and carry on any kind of production. This kind of finance can be properly named initial finance and must cover the total cost of the planned amount of production, no matter what the nature of the product (consumer goods or capital goods)' (Graziani 2003, p. 69, emphasis in original ${ }^{3}$ ). Graziani (pp. 69-70) spoke of final finance as 'the liquidity collected by firms either selling commodities or issuing securities', and the 'role of final finance ... to make it possible to firms to repay their bank debt'. When related to the financing of investment, 'investment finds its final finance in saving' (p. 71, emphasis in original).

Graziani distinguished between the financing of production and the financing of investment. The former is required for any type of production, specifically whether consumer goods or capital goods, whereas the latter is such that 'investment finds its final finance in saving' (p. 77, emphasis in original). He also argued that there is a confusion between 'the problem of financing production (namely of creating an adequate amount of liquidity for inputs and output to be circulated in the market) and financing

2. Van der Zwan (2014) identifies three broad approaches within financialisation: these are 'financialization as a regime of accumulation', 'the financialization of the modern corporation', and 'the financialization of the everyday'. A further dimension would be de-regulation and liberalisation of the financial system. These are important dimensions of financialisation but I would argue they do not have significant implications for the circuitist analysis.

3. Page numbers following quotes refer to Graziani (2003) unless otherwise stated. 
investment (namely creating an equal amount of overall saving). The confusion between initial and final finance is still widespread in the literature' (p. 56, emphasis in original).

This is clearly related to Keynes $(1937$, p. 663, fn 2) when he wrote that he was there using "the term "finance" to mean the credit required in the interval between planning and execution'. And then 'the banks hold the key position in the transition from a lower to a higher scale of activity ... The investment market can become congested through shortage of cash. It can never become congested through shortage of savings' (ibid.).

The circuitist analysis is undertaken at a relatively high level of abstraction, and the assumptions on the institutions of the economy reflect that. Three sets of institutions are identified, namely banks, firms and households operating in what is viewed as capitalist economy. The institutions which are identified are given minimum properties for the analysis, and it is relevant to consider what those properties are. This is an issue shared with much macroeconomic analysis, where the analysis (model) uses terms that have real world counterparts but where there is often a lack of correspondence between the way the term is used in macroeconomic theorising and the real world counterpart. The one which is often pointed out to students is 'investment', which is used in macroeconomic analysis to signify capital formation, whereas it is used in a range of ways in the real world including a shorthand for the acquisition of financial assets. The two that particularly concern us here are 'households' and 'banks'. In the circuitist analysis the key properties assigned to households are as consumer, saver and provider of labour. In the national accounts the household sector includes small business activity, and hence the household sector is reported as undertaking substantial investment. ${ }^{4}$ There is thus not a direct correspondence between 'households' in macroeconomic analysis and the household sector in the national accounts. The properties assigned to 'bank' are more significant. In the circuitist analysis (and indeed macroeconomic analysis), the essential features of banks are that in the process of granting loans money is created (in the form of bank deposits) as banks are financial institutions whose liabilities are widely accepted as a means of payment. In the real world, the term 'banks' is often used to signify financial institutions who accept deposits, and are often regulated and given legal status. Some banks (in the legal sense) are not banks in the sense used in circuitist and macroeconomic analysis. It is then relevant to distinguish between what I will term clearing banks (other terms such as commercial banks could be used) and investment banks and savings banks (to cover those institutions who accept deposits and make loans, with the former servicing firms and the latter servicing households). Clearing banks are then financial institutions whose liabilities (deposits) are generally accepted as means of payment and are readily transferable between economic agents. Money is viewed in terms of a means of payment, and any financial asset with value fixed in terms of the unit of account and generally accepted as a means of payment is treated as money. The liabilities of investment and savings banks in contrast are not immediately transferable between economic agents, though such deposits are fixed in value in terms of the unit of account and may be treated as 'near-moneys', especially where the deposits can be accessed at short notice. The clearing (commercial) banks create liquidity whereas the investment and savings banks circulate the existing liquidity between savers and investors.

4. The UK national accounts indicate that gross fixed capital formation reported in the household sector is around half of that reported for the corporate sector. 
These are the essential properties that are assigned to clearing banks and to investment banks and savings banks below. However, a complication arises in that an actual financial institution (for example, a universal bank) may be a clearing bank, an investment bank and a savings bank, and when the relationships between clearing banks and investment banks are discussed below, these could be relationships within a single institution. There is then a need to ensure that care is taken in understanding the nature of the institutions assumed in the analysis and the nature of the institutions in the world which bear the same label, and to what degree there is a correspondence between the two.

There are two obvious, but often ignored in the neoclassical world, features of production: production takes time, and production of goods and services has to precede (or in the case of some services go alongside) use, whether as investment goods or consumption goods. In general, the payment by the customer for the purchase of a product comes after production. Production may be undertaken to order by the purchaser or undertaken in the anticipation of sales. In either case, the production processes, purchase of labour and materials have to be financed. The circuitist approach is indeed a theory of monetary production: it focuses on the financing requirements for production to occur, for firms to acquire materials and labour. Any expenditure on the purchase of goods and services has to be financed, and the finance for expenditure can be separated into that which is utilising existing money (bank deposit) and that which draws on loans from banks and the creation of 'new' money. There are in effect always a series of overlapping circuits, and the fulfilment of one circuit requires that other circuits have been opened. A notable example here being that workers are hired and paid wages, with which they purchase goods and services. In turn those goods and services have to be produced prior to their purchase and consumption by workers. Thus the circuit involved in the production of the goods and services to be consumed by workers to consume must have opened. This point can be extended to allow that workers and households take out money creating loans, thereby opening a supplementary circuit. In effect, it is argued that attention should be paid to the financing of expenditure as well as the financing of production, whilst recognising that the latter generally precedes the former. There are then in effect overlapping circuits, and a specific circuit has to be located within other circuits.

The steps within a circuit were set out by Graziani (pp. 27-31) as follows:

Step one: A decision is taken to grant credit to firms, thus enabling them to state a process of production

Step two: The second phase of the economic process consists in the decisions concerning production and expenditure

Step three: In the third phase, commodities produced are put on sale. Consumer goods are sold to wage earners, while investment goods are exchanged inside the firms sector

Step four: Once the initial bank debt is repaid and the money is destroyed, the monetary circuit is closed

Step five: So far, the above description has omitted the problem of the payment of interest to the banks.

Let us start with the simplest case, where the circuit relates to the financing of production of consumption goods and without investment goods. In order for production to be undertaken, it needs to be financed and for this purpose a loan is secured from a bank. The opening and then closing of this (very) simple circuit are illustrated in Table 1, with the flows portrayed in Figure 1. The deposits are spent by firms on wages, which in turn are spent on the goods and services which have been produced by the firms. The deposits return to firms, and those deposits are utilised to pay off the loans. 
Table 1 Simple circuit

\begin{tabular}{|c|c|c|c|}
\hline \multicolumn{4}{|c|}{ Opening } \\
\hline \multicolumn{2}{|c|}{ Firms } & \multicolumn{2}{|c|}{ Clearing banks } \\
\hline Assets & Liabilities & Assets & Liabilities \\
\hline Deposits & Loans & Loans & Deposits \\
\hline \multicolumn{4}{|c|}{ Closing } \\
\hline \multicolumn{2}{|c|}{ Firms } & \multicolumn{2}{|c|}{ Clearing banks } \\
\hline Assets & Liabilities & Assets & Liabilities \\
\hline Zero & Zero & Zero & Zero \\
\hline
\end{tabular}

Note: Assets and Liabilities refer to difference to base case.

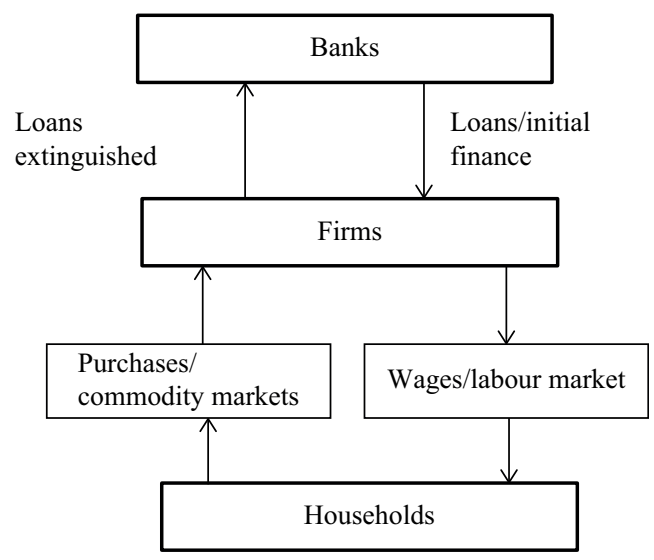

Figure 1 A simple circuit

This simple circuit illustrates several features of the circuitist analysis. First, the circuit opens with firms seeking to undertake production, presumably in anticipation of being able to sell at a profit what is produced. The expectations on which the firms have based their decisions and the expectations on which banks base their decisions on loans are not specifically addressed. Second, the circuit is taken to operate in a rather smooth manner in which workers are hired, wages paid and then fully spent (hence no hoarding of bank deposits), and in which the composition of expenditure intended by households matches the composition of production undertaken by firms (and this may be achieved through firms' price setting to be able to sell what has been produced). There are no significant delays in production through the unavailability of the required material inputs. There are strong overtones of the circuitist analysis referring to 'normal times', and on the achievement of equilibrium outcomes. However,

'[e]quilibrium' as defined by the theory of the circuit is not necessarily unique or stable. It is in fact in the nature of circuit analysis to allow for a multiplicity of possible 'equilibria', depending on the strategies of banks and firms. This view is reinforced by the fact that, the money stock being endogenous, no Pigou effect can be invoked as a stabilizer of last resort. (Graziani 1990, p. 31) 
Third, Graziani argued that 'it is clear that if, instead of considering firms as a whole, we were considering a single isolated firm, the situation would be different ... Still the simplified aggregate representation by no means alters the substance of the picture' (Graziani 2003, p. 27). Firms are treated as 'as one integrated and consolidated sector, the only purchase firms have to make before starting production is to hire labour, and their only payment is the wage bill. All other exchanges can be neglected, being internal to the firm sector. Therefore the demand for bank credit coming from the producers depends on the wage rate and on the number of workers that firms intend to hire...' (p. 27). Thus the interactions between firms is aggregated out - hence the buying and selling of material inputs does not appear explicitly. For the purposes of the circuitist analysis this is not of central importance, but it does add to the view that the circuit is assumed to proceed smoothly and there are no coordination failures in this case in respect of material inputs.

The fourth feature is that the production of material inputs and the production of consumer goods and services would in general require the opening of additional circuits. The production of material inputs and the consumer goods to be purchased in turn each require initial finance. It would not, in my view, undermine the circuitist analysis if it were also permitted that loans were provided to finance consumer expenditure. One implication which arises from that observation is that a single period circuitist analysis needs to be embedded in a sequence of overlapping circuits.

Fifth, the bank deposits return to firms in general, and the firms receiving the deposits do not necessarily match with the firms that have taken out the loans at the beginning of the circuit. The distribution of the deposits between firms will not in general correspond to the distribution of loans between firms, and inter-firm lending and borrowing would be required. The circuitist analysis has focused on firms as a whole with little attention paid to this redistribution. This is an issue to which I return below.

Finally, it is a single period analysis where the length of the period is set by the closing of the circuit and hence does not have a calendar time length, and the length of the single period depends on the adjustment processes. However, the circuitist analysis can clearly become part of a multi-period analysis in which outcomes from one period influence decisions in the next period and in which flows from one period add to stocks which influence future behaviour. The Hicksian distinction between single period and continuation period (Fontana 2009, ch. 6) would provide one fruitful way of thinking about such issues.

\section{INVESTMENT AND THE CIRCUIT}

The next step is the introduction of investment and investment goods into a circuit. The circuit again starts with loans taken out for the production of investment goods, and again production has to precede use. The financing of the purchase of the investment goods may involve the opening of a supplementary circuit, that is, bank loans are extended to firms to enable them to purchase investment goods. Savings are also undertaken, and for simplicity it is assumed that it is only households that save. In a calendar period of time, there would be some element of 'forced savings' for households, in that inflow of income exceeds outflow of expenditure in that period even though the intention is for subsequent expenditure. Further, savings at the household level occur first in the form of accumulation of bank deposits through the excess of inflow over outflow of bank deposits. In subsequent calendar time periods, expenditure proceeds on the basis of the prior receipt of income. Conceptually, two further 
Table 2 Circuit with investment: first stage of closure

\begin{tabular}{|c|c|c|c|c|c|}
\hline \multicolumn{2}{|c|}{ Households } & \multicolumn{2}{|c|}{ Firms } & \multicolumn{2}{|c|}{ Clearing banks } \\
\hline Assets & Liabilities & Assets & Liabilities & Assets & Liabilities \\
\hline Deposits & - & Capital stock & Loans & Loans & Deposits \\
\hline
\end{tabular}

Note: Household savings held as bank deposits.

Table 3 Closing of circuit with investment

\begin{tabular}{|c|c|c|c|c|c|c|}
\hline \multicolumn{2}{|c|}{ Households } & \multicolumn{2}{|r|}{ Firms } & \multirow{2}{*}{$\frac{\text { Clearing banks }}{\text { Assets Liabilities }}$} & \multicolumn{2}{|c|}{ Investment banks } \\
\hline Assets & Liabilities & Assets & Liabilities & & Assets & Liabilities \\
\hline $\begin{array}{l}\text { Deposits with } \\
\text { investment } \\
\text { bank }\end{array}$ & - & $\begin{array}{r}\text { Capital } \\
\text { stock }\end{array}$ & $\begin{array}{l}\text { Loans from } \\
\text { investment } \\
\text { bank }\end{array}$ & $-\quad-$ & $\begin{array}{l}\text { Loans to } \\
\text { firms }\end{array}$ & $\begin{array}{l}\text { Deposits } \\
\text { from } \\
\text { households }\end{array}$ \\
\hline
\end{tabular}

stages towards the end of the circuit can be identified. At the end of the first stage, savings held by the household are voluntary in the sense that they have no further plans to spend. The skeleton accounts are then as shown in Table 2, where the deposits held by households correspond to their savings at this stage.

In the second stage, households use bank deposits to acquire financial assets, and firms (directly or indirectly) swap their bank loans for other financial liabilities. To show this, investment banks are introduced which provide financial assets for households and financial liabilities to firms. The key feature of investment banks is that of a financial intermediary that accepts deposits from households on which interest is paid and provides loans to firms for which interest is charged. For investment banks, unlike clearing banks, deposits make loans, and deposits with them are not transferable between economic agents and hence are not to be regarded as money. The accounts at the end of the second stage now appear as shown in Table 3.

The circuit is presented here as now being closed, in that the loans from clearing banks are fully paid off and the corresponding money (bank deposits) destroyed. It is easy to envisage situations in which the circuit is not fully completed, for example when households find it convenient to hold some of their savings in the form of bank deposits. Although it is not possible to be precise on the determination of interest rates in this framework, it could be expected that $r 1$ (rate of interest on clearing bank loans) $>r 2$ (clearing bank deposits) to provide profits for the clearing banks (where $r 1$ is adjusted for loan defaults and $r 2$ could be zero or even negative if bank charges were factored in), and $r 3$ (interest rate on investment bank loans) $>r 4$ (investment bank deposits), and further that $r 1>r 3$ (for otherwise firms would not switch from clearing bank loans to investment bank loans), and $r 4>r 2$ (similarly for households to switch from clearing bank deposits to investment bank deposits).

\section{HOUSEHOLDS AND THE CIRCUIT}

The circuit is based on a monetary theory of production, and by definition households are consumers and workers and not producers, and as such household borrowing and debt would at first sight appear to be inconsistent with the circuitist approach. As Graziani notes, 'circuit theorists usually assume that only firms are 
admitted to bank credit' (p. 27). In the consideration of household borrowing it is argued that a distinction should be drawn between loans from banks which thereby create bank deposits and other borrowing from financial institutions (including some which may bear the label of banks).

It is generally observed that there has been a substantial rise in household debt in many countries over the past few decades, and this has been seen as a significant element in the processes of financialisation. Using figures from UK national accounts, the financial liabilities of households in 2013 amounted to the equivalent of 96 per cent of GDP and 147 per cent of household disposable income. But financial assets of households amounted to 307 per cent of GDP (468 per cent of disposable income) and non-financial assets 282 per cent of GDP (430 per cent of disposable income). ${ }^{5}$ This level of assets and liabilities (and their general growth) is another reflection of a general tendency for financial assets and financial liabilities to grow faster than GDP and the capital stock.

In the context of the circuitist analysis, there are two questions. First, what does the presence of household debt say about the financing of household expenditure and the use of bank loans (and thereby money creation) by households. It would be feasible to think of an arrangement whereby households did not have access to bank loans but nevertheless entered into debt - much funding of house purchase being of that form. Graziani (p. 21, fn 9) wrote that:

More often than not, contemporary literature insists on the fact that credit granted to households equals or even exceeds credit granted to firms ... . It is however highly debatable whether credit granted to households is really given to consumers or rather is in fact indirectly granted to firms, by allowing consumers to buy finished products.

Households taking out loans from banks which are money creating have long been a feature of some banking systems, often operating through overdraft facilities. Following on from remarks above, a different perspective is adopted, namely that households borrowing from clearing banks to finance consumer expenditure should be seen in terms of the opening of a supplementary circuit, akin to that which firms financing investment expenditure are viewed. In the single period analysis there may then be little difference between household borrowing (for consumer expenditure) and firms borrowing (for investment expenditure) from clearing banks, though the latter generate savings whereas the former do not generate net savings though some households have positive savings while others dissave. The differences would arise in a multiperiod analysis, particularly in terms of the repayment of loans and the sustainability of such borrowing.

The second aspect relates to the funding (final finance) of household debt. In the traditional circuitist framework, households save and firms invest (and also save), and the savings of households and firms fund the investment of firms. The households cumulate financial assets, and the firms cumulate financial liabilities (and of course cumulate real capital assets). Now households hold both assets and liabilities (debt), though are in a net asset position, and corporations hold financial assets, some of which may correspond to the financial liabilities of households (for example, consumer loans). The overall effects of these observations is that the flows of funds between sectors are more complex than envisaged in the simple circuit analysis but do not

5. As noted above, in national accounts terms households include small businesses and hence the assets and liabilities will include those relating to some business activities. 
Table 4 Creditor and debtor households: closing of circuit

\begin{tabular}{|c|c|c|c|c|c|}
\hline \multicolumn{2}{|c|}{ Creditor households } & \multicolumn{2}{|c|}{ Debtor households } & \multicolumn{2}{|c|}{ Savings banks } \\
\hline Assets & Liabilities & Assets & Liabilities & Assets & Liabilities \\
\hline Deposits & - & - & Loans & Loans & Deposits \\
\hline
\end{tabular}

change the essence of the circuitist analysis which we see as based on the distinction between initial finance and final finance.

Now consider the case where there is no investment but some households take out loans from clearing banks to finance consumption. Rather than largely repeating the exercises above, we can move directly to the end of the circuit, now distinguishing between two types of households, debtors and creditors. Further, we use the term savings bank to signify a financial institution which accepts deposits from households and which provides loans to households. The end accounts are then as shown in Table 4.

The circuit is again closed. A specific question which would arise is period-to-period sustainability. Interest payments would flow from debtor households to creditor households. If the identity of the creditor households and the debtor households remains unchanged, there would clearly be sustainability issues. However, if the identity changes (that is, households switch between categories), it could be sustainable. An example here would be where savings and dissavings effect an intergenerational transfer: creditor households who are saving are the 'young' whereas the debtor households who are dissaving are the 'old' - and the 'young' eventually become 'old'. This is an illustration of the point made above, namely the need to proceed from the single period analysis to a continuation period.

It has been argued that one feature of financialisation has been a tendency for some corporations to become net lenders rather than net borrowers and for their savings (out of profits) to exceed their investment expenditures. We could repeat an exercise similar to that just undertaken to enable firms to undertake savings and households to undertake dissavings. But rather than do so, I will later reflect that possibility in the more elaborate circuit below and the associated flows between sectors.

\section{FINAL FINANCE AND THE CIRCUIT}

The important distinction in the circuitist analysis is between initial finance and final finance. When investment is included in the circuit then, as seen above, savings are generated, initially in the form of the accumulation of bank deposits. On the one side, households seek to hold their savings in the form of financial assets, and on the other side firms seek to fund their investment through the issue of financial assets. In the circuit, the volume of savings generated is equal to the volume of investment expenditure, with, of course, causation running from investment to savings. The composition of the financial assets held by households has, at the end of the circuit, to match the composition of financial liabilities issued by firms. The matching process takes place through many channels and financial institutions: though in the example above, investment banks were the only channel.

Graziani (2003) chapter 6 has a discussion of 'the role of financial markets', where the term market is used broadly to include the role of banks. The term 'financial sector' is however preferred over the term 'financial markets', with the recognition that the financial sector is composed of many different types of institutions and different 
relationships between those financial institutions with firms and households. The term 'financial institution' would include stock markets (whether formally or informally organised), its institutional arrangements and the role of 'market makers', as well as banks of various types. The financial sector can be viewed as potentially fulfilling two related roles: one is the matching of savings with the volume of new financial assets issued (which would include new equity, savings deposits), and the other, at the micro level, is the matching of the demands to hold different financial assets with the willingness of the financial sector and firms to issue different financial assets. That is to say, if there is a financial asset type $A$, then the willingness to hold 'new' $A$ has to match willingness to provide 'new' $A$. At one level this could be treated as an accounting requirement between the issue of $A$ and the holding of $A$. At another level, an equilibrium structure of interest rates and returns could be constructed - a journey on which Graziani (2003) appears to start - and one which many others have travelled.

To consider final finance and its allocation, the financial institutions included in the circuit are added to by the inclusion of non-bank financial institutions (NBFIs, 'shadow banks') as well as investment banks and savings banks. The distinction that is drawn is between investment and savings banks which accept deposits whose value is fixed in terms of the unit of account and non-bank financial institutions which deal in financial assets and liabilities more generally.

With this minimal extension to the types of financial institutions, and other extensions discussed above, the circuitist framework is now illustrated in Figure $2 .{ }^{6}$ By comparison with the simple circuit involving investment (that is, the one summarised in Tables 2 and 3), this representation incorporates (i) household borrowing, (ii) savings flows from households passing through two types of financial intermediaries (the investment and savings banks and the NBFIs), and (iii) savings undertaken by firms which flow to financial institutions.

In accounts terms, the completion of the circuit would be represented as in Table 5 . The assets and liabilities of the clearing banks at the end of the circuit are treated as zero with final finance in place (and not separately reported in the table). At the end of the circuit, in terms of Table 5, households have savings (and hence assets) held in the form of deposits with investment/savings banks $(A 1)$ and with NBFIs ( $A 2)$, and dissaving (liabilities) of $L 1$ (consumer debt); firms have real assets of $K$ (capital formation), and financial assets $A 3$ and $A 4$, and liabilities $L 2$ and $L 3$. Investment and savings banks have assets in the form of lending to households and firms, and liabilities in the form of deposits accepted from households and firms. Non-bank financial assets similarly have assets of $L 3$ and liabilities of $A 2$ and $A 4$.

The circuitist analysis focuses on the outcomes rather than the processes by which those outcomes are achieved. In Figure 2, the flows between the institutions are signified by arrows. This says nothing about the nature of the relationship between the institutions at the ends of the arrows. As has been argued above, the spectrum of interest rates and rates of return on financial assets would need to be consistent with the composition of assets and liabilities, that is, such that $L i=A i(i=1,2,3,4)$ are the equivalent of equilibrium conditions. In effect, what would be required here is the extension of Graziani (2003) chapter 6 in three ways. The first is that the range of financial assets and liabilities to be considered would need to be appropriately extended. The second is that the financial institutions would need to be included with income being generated by the financial institutions from (in effect) the difference between interest and other returns paid on financial assets and the payments made on

6. This figure is a development of one presented in Veronese Passarella and Sawyer (2014). 


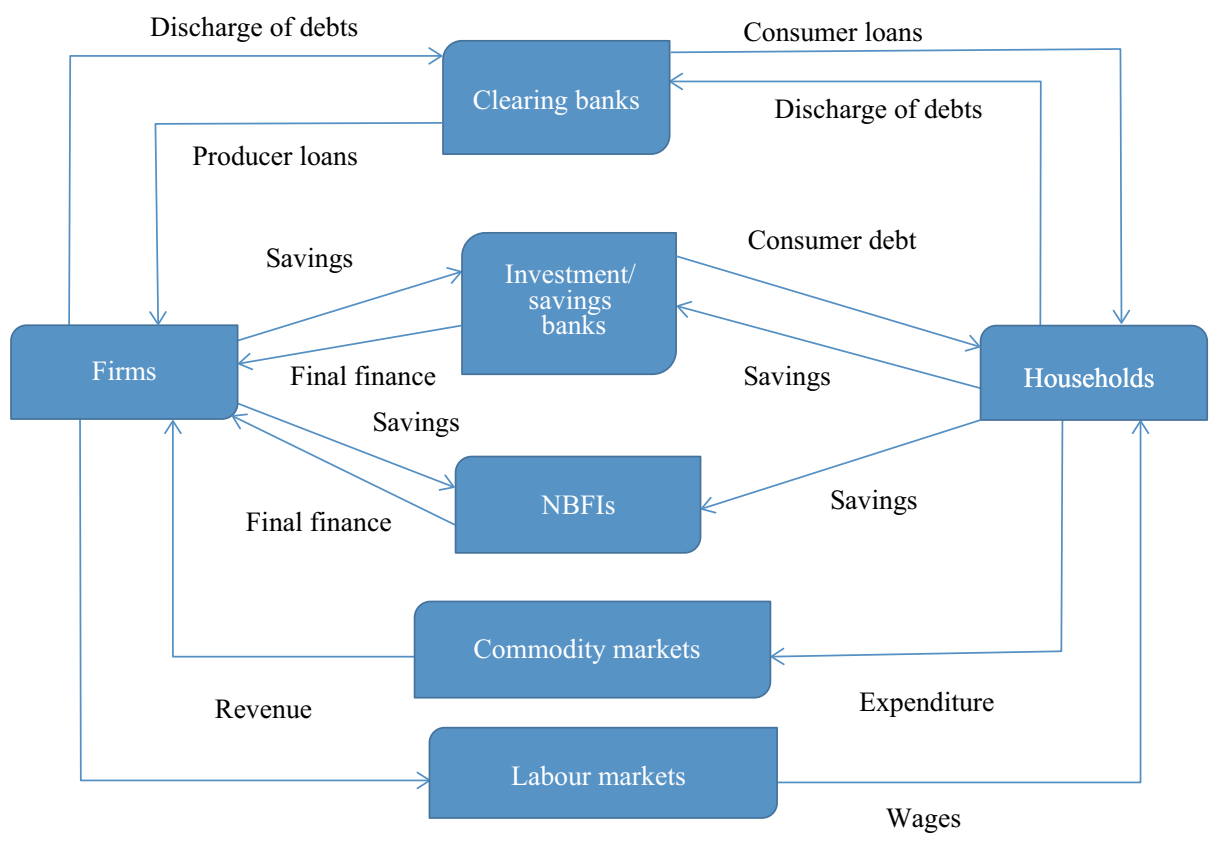

Figure 2 A more complex circuit

Table 5 Final finance configuration

\begin{tabular}{|c|c|c|c|c|c|c|c|}
\hline \multicolumn{2}{|c|}{ Households } & \multicolumn{2}{|c|}{ Firms } & \multicolumn{2}{|c|}{ Investment/savings banks } & \multicolumn{2}{|c|}{ NBFIs } \\
\hline Assets & Liabilities & Assets & Liabilities & Assets & Liabilities & Assets & Liabilities \\
\hline$A 1, A 2$ & $L 1$ & $K, A 3, A 4$ & $L 2, L 3$ & $L 1, L 2$ & $A 1, A 3$ & L3 & $A 2, A 4$ \\
\hline
\end{tabular}

financial liabilities. The third would be the consideration of the processes through which some form of equilibrium is attained.

Figure 2 provides an illustration that many of the developments of the economic and financial system associated with the term 'financialisation' do not undermine the 'circuitist analysis' which is built on the distinction between initial finance and final finance, and the creation of money for initial finance as the opening of a circuit.

The circuit such as that portrayed in Figure 2 and Table 5 provides a framework within which a number of questions can be approached.

It has been remarked above that the circuitist analysis does not and was never meant to provide a detailed institutional analysis, nor does it provide an in-depth analysis of the behaviour and interactions of economic agents. These remarks would have two aspects. The first is that the examination of any existing financial sector would have to specify in some detail the nature and operations of different types of financial institutions. Further, there are trades within each of the sets of institutions to be examined and in the case of financial institutions this is of particular significance regarding the degree to which NBFIs develop financial products for trade with other financial institutions (for example, derivatives, securitisation). There are, of course, many such examinations, and those such as Poznar (2014) and others based on the 'money 
view' (as developed by Perry Mehrling) could be viewed as fitting in well with the framework of Figure 2.

The second would relate to the nature of the contractual relationships involved between the financial institutions (banks and NBFIs) and firms. These range from the monitoring of loan contracts, the manner in which credit rationing operates and the ownership of equity of corporations by financial institutions. The last of those has relevance for the 'pursuit of shareholder value' in that the financial institutions are the shareholders.

The circuitist analysis has tended to be a single period analysis in which flows between specified sets of institutions are portrayed. As such it has to be complemented by multi-period analysis and by market arrangements which determine the scale and composition of the flows identified. There are many ways in which this could be (and is being) done, including stock-flow consistent modelling. In doing so, the circuitist framework would provide the general framework within which the specifics of an economy can be explored.

\section{CONCLUDING REMARKS}

The basic argument of this paper is that the central features of the circuitist analysis - the distinction between initial finance and final finance, and the opening of a circuit based on bank loans to enable firms to undertake production - are valid, and in a monetary production economy are necessarily relevant. However, the simple circuitist analysis is typically presented as a single-period thought experiment with minimal institutional assumptions and with an aggregation of the production firm sector. This aggregation can serve to obscure the full workings of the circuit in which many transactions form part of a circuit as money passes from one firm to another. It is further argued that there should be recognition of supplementary circuits arising from loans and initial finance for investment and consumption expenditure, recognising that production has to precede in time consumption (though production intentions are strongly influenced by expectations on consumption demand). The circuist framework enables answers to a range of questions to be sought, including how and why the circuit opens, that is, why firms decide to undertake production, why banks are willing or unwilling, and on what terms, to provide loans; and the nature of disruptions to the completion of the circuit.

The circuitist analysis clearly recognises that investment expenditure is initially financed by bank loans, and that final finance corresponds to savings undertaken by households and firms which are recycled to fund the investment expenditure. The circuitist analysis has paid little attention to the ways in which the savings (in the form of money holdings) are allocated to the funding of investment. This should not be seen as a loanable funds approach, in that the investment has preceded the savings. The ways in which there is a matching of financial assets acquired and financial liabilities issued are complex and analysis of those ways needs to be added to complete the circuitist analysis. Sawyer and Veronese Passarella (2016) use a stock-flow consistent model to undertake a preliminary step in that direction.

\section{REFERENCES}

Epstein, G. (2005), 'Introduction: financialization and the world economy', in G. Epstein (ed), Financialization and the World Economy, Cheltenham, UK and Northampton, MA: Edward Elgar, pp. 3-16. 
Fontana, G. (2009), Money, Uncertainty and Time, London: Routledge.

Graziani, A. (1990), 'The theory of the monetary circuit', Economies et Societies, Monnaie et Production, 7, 7-36.

Graziani, A. (2003), The Monetary Theory of Production, Cambridge, UK: Cambridge University Press.

Keynes, J.M. (1937), 'The "ex ante" theory of the rate of interest', Economic Journal, 47(188), 663-669.

Pozsar, Z. (2014), 'Shadow banking: the money view', Office of Financial Research working paper, no 14-04.

Sawyer, M. (2013), 'What is financialization?', International Journal of Political Economy, 42(4), $5-18$.

Sawyer, M. and M. Veronese Passarella (2016), 'The monetary circuit in the age of financialisation: a stock-flow consistent model with a twofold banking sector', Metroeconomica, forthcoming (available online as advanced publication).

Van der Zwan, N. (2014), 'State of the art: making sense of financialization', Socio-Economic Review, 12, 99-129.

Veronese Passarella, M. and M. Sawyer (2014), 'Financialisation in the circuit', FESSUD Working Papers No 19. 